\title{
Impact of Economic Policy Uncertainty on Renewable Energy Growth
}

\author{
Isaac Appiah-Otoo ${ }^{1}$ (1) \\ ${ }^{1}$ School of Management and Economics, Center for West African Studies, University of Electronic Science and Technology of China (UESTC) \\ Keywords: renewable energy, economic policy uncertainty, panel data \\ https://doi.org/10.46557/001c.19444
}

\section{Energy RESEARCH LETTERS}

Vol. 2, Issue 1, 2021

This study examines the effect of economic policy uncertainty (EPU) on renewable energy (RE) growth for 20 countries using data for the 2000 to 2018 period. Our findings indicate that EPU has an insignificant negative effect on RE growth. The results from the causality analysis indicate no evidence of causality between EPU and RE growth.

\section{INTRODUCTION}

Renewable energy (RE) promotes environmental sustainability, dynamic economic development, energy independence, and security (Bourcet, 2020). However, its worldwide use is low compared to other energy sources (Bourcet, 2020). Several variables, such as economic growth, trade openness, carbon emissions, population growth, technological innovation, financial development, energy consumption, energy security, energy prices, institutional quality, government ideology, the Kyoto protocol, and feed-in-tariffs have been shown to impact RE utilization (see Bourcet, 2020). However, not much is known about the impact of economic policy uncertainty (EPU) on RE deployment.

EPU captures the likelihood that future economic and political policies shift from those in the current period (Baker et al., 2016). Specifically, EPU captures the component of the usual uncertainty in economics that is attributable to political and regulatory structures and reflects records about concurrent and future cash flows, financing, and investment opportunities, which are relevant to liquidity administration (Li, 2019).

According to Al-Thaqeb \& Algharabali (2019), the past decade has witnessed rapid political and economic uncertainties. Some of the main ones include the "Arab Spring", Russia's capture of Crimea and the refugee predicament, "Brexit" coupled with increased migration, unemployment, trade frictions, and income inequality. The most recent one is the COVID-19 pandemic, which has also increased global uncertainties (Appiah-Otoo, 2020; Iyke, 2020), with uncertainties impacting economic growth, financial development, stock returns, investment, household consumption and saving decisions, innovations, tourism, firms' cash flow, and bank stability (Al-Thaqeb \& Algharabali, 2019). What role EPU plays in influencing RE growth is unexplored.

Balcilar et al. (2019) explain that uncertainties affect RE growth in the following ways. First, its adverse impact on the macroeconomy hinders RE growth due to investment challenges and the change to other sources of energy that are more affordable. Second, faced with growing uncertainties (as reflected in the EPU), policymakers become reluctant to adopt RE policies given the activities of consumers and producers, who may stick to their current energy use.

In this note, we examine the effect of EPU on RE growth (measured by the share of RE in electricity production) for 20 countries, namely Australia, Brazil, Canada, the US, the UK, Sweden, Spain, Singapore, China, Russia, the Netherlands, Mexico, the Korea Republic, Japan, Ireland, India, Hong Kong, Greece, Croatia, and Colombia. Our data covers the 2000 to 2018 period. These countries were selected given data availability on EPU over the study period. Besides, the share of RE in the total electricity mix is very low in most of the countries under study except Brazil, Colombia, Croatia, Canada, and Sweden. Finally, most of these countries have high levels of EPU, except India, Australia, Sweden, and the Netherlands.

We contribute to the literature on uncertainties and RE growth in the following way. This study presents the first empirical estimate of the effect of EPU on RE growth. Nguyen et al. (2020) have studied the effect of EPU on macro and microeconomic variables; however, whether EPU affects RE growth is unexplored. Thus, this study estimates the effect of EPU on RE growth. Additionally, we disaggregate RE into hydroelectricity and other RE sources to address the issue of homogeneity in RE. Furthermore, we examine the causal relationship between EPU and RE growth. Finally, to produce consistent results, we use the instrumental variables generalized method of moments (IVGMM) model, which addresses endogeneity and omitted variable issues (Appiah-Otoo \& Song, 2021).

The rest of the paper is presented as follows. Section II discusses the literature and hypothesis development. Section III reports on the data and the empirical model, whilst Section IV presents the results and discussions. Section V discusses the conclusion and policy recommendations.

\section{LITERATURE REVIEW AND HYPOTHESIS DEVELOPMENT}

Barradale (2010) examines the effect of public policy uncertainty in the US wind industry using survey data obtained from energy professionals and finds that public policy uncertainties reduce investment in the wind industry. Fabrizio (2013) examines the impact of regulatory uncer- 
Table 1: Variable definition

\begin{tabular}{|c|c|c|c|}
\hline Variables & Full name & Definition & $\begin{array}{l}\text { Unit of } \\
\text { Measurement }\end{array}$ \\
\hline Inre & $\begin{array}{l}\text { Renewable energy } \\
\text { growth }\end{array}$ & Share of renewable energy in electricity production & Percent \\
\hline Inhydro & Hydroelectricity & Electricity from hydropower plants & Percent \\
\hline Inothers & $\begin{array}{l}\text { Other renewable } \\
\text { energy sources }\end{array}$ & $\begin{array}{l}\text { Electricity from geothermal, tides, solar, biomass, wind, and } \\
\text { biofuels }\end{array}$ & Percent \\
\hline Ingdp & $\begin{array}{c}\text { Gross domestic } \\
\text { product (GDP) per } \\
\text { capita }\end{array}$ & Economic growth divided by the total population & $\begin{array}{c}\text { Constant } 2010 \\
\text { US\$ }\end{array}$ \\
\hline Into & Trade openness & Sum of export and import as a percentage of GDP & Percent \\
\hline Inco2pc & $\begin{array}{l}\text { Carbon emissions per } \\
\text { capita }\end{array}$ & Carbon dioxide emissions divided by the total population & $\begin{array}{l}\text { Metric tons per } \\
\text { capita }\end{array}$ \\
\hline Inpopg & Population growth & Rate of increase in population & Percent \\
\hline Inrnd & $\begin{array}{l}\text { Technological } \\
\text { innovation }\end{array}$ & Research and development expenditure & $\begin{array}{l}\text { Percentage of } \\
\text { GDP }\end{array}$ \\
\hline Inene & Energy consumption & Energy use & $\begin{array}{c}\text { Kg of oil } \\
\text { equivalent per } \\
\text { capita }\end{array}$ \\
\hline Indcps & Financial development & Domestic credit to the private sector & $\%$ GDP \\
\hline Inepu & $\begin{array}{l}\text { Economic policy } \\
\text { uncertainty }\end{array}$ & $\begin{array}{l}\text { The probability that future policies will vary from the current } \\
\text { policies and how it will impact economic activities. }\end{array}$ & Index \\
\hline
\end{tabular}

This table contains the variables, their full names, definition, and their unit of measurement.

tainties on RE firms' investment in the US and finds that $\mathrm{RE}$ investment stalled for states with regulatory uncertainties. Cao et al. (2019) examine the effect of oil price volatilities on RE firms' investment in China and find that oil price uncertainties reduce RE firms' investment. Balcilar et al. (2019) examine the effect of four different proxies of energy market uncertainties on RE growth for 28 European countries from 1990 to 2015 and find that demand, residual energy, and oil price uncertainties promote RE growth, while supply price uncertainties impede RE growth. However, studies have not employed the new index of EPU developed by Baker et al. (2016) to estimate the effect on RE growth. Thus, this study aims to fill this gap.

We test the hypothesis that the effect of EPU on RE growth is negative. This hypothesis is motivated by the real option's theory, which argues that firms delay their investment when they are faced with uncertainty (Hsieh et al., 2019). Testing this hypothesis is vital given the surge in global uncertainties, which affect stakeholders in the energy sector (Balcilar et al., 2019).

\section{DATA AND METHODOLOGY}

\section{A. DATA}

This study utilizes data on RE growth, EPU, economic growth, trade openness, carbon emissions, population growth, technological innovation, financial development, and energy consumption for 20 countries for the period
2000 to 2018. We disaggregate the total RE into hydroelectricity and other renewable energy sources. We obtain the data on EPU from www.policyuncertainty.com and data on the other variables are from the, World Development Indicators database ${ }^{1}$. We use the log form of the variables to interpret the results as elasticities.

Table 1 contains the variables, their full names, definition, and their unit of measurement.

\section{B. EMPIRICAL FRAMEWORK}

Following da Silva et al. (2018), the empirical model underlying this study is as follows:

$$
\begin{aligned}
\text { lnre }_{i t}= & b_{o}+b_{1} \operatorname{lngdp}_{i t}+b_{2} \text { lnepu }_{i t} \\
& +b_{3}{\operatorname{lnco} 2 p c_{i t}+b_{4} \text { lnto }_{i t}} \\
& +b_{5} \operatorname{lndcps}_{i t}+b_{6} \text { lnrnd }_{i t} \\
& +b_{7} \operatorname{lnpopg}_{i t}+b_{8} \text { lnene }_{i t}+\varepsilon_{i t}
\end{aligned}
$$

where lnre represents total RE growth which is further divided into hydroelectricity lnhydro and other RE sources, lnothers. lnepu is EPU, lnco2pc represents carbon emissions per capita, lnto is trade openness, lndcps is financial development, lnrnd represents technological innovation, lnpopg denotes population growth, lnene is energy consumption; $\varepsilon_{i t}$ denotes the error term; and $i$ and $t$ represent country and time, respectively. The aim of this study is to estimate $b_{2}$ in Equation (1). We expect $b_{2}$ to have a statistically significant and negative effect on RE growth.

We Estimate (1) with the IV-GMM model. This model 
Table 2: Descriptive Statistics

\begin{tabular}{|c|c|c|c|c|c|}
\hline Variables & Obs & Mean & SD & Min & Max \\
\hline Inre & 314 & 2.508 & 1.616 & -5.965 & 4.494 \\
\hline Inhydro & 288 & 2.220 & 1.695 & -2.995 & 4.469 \\
\hline Inothers & 311 & 0.622 & 1.722 & -5.965 & 3.277 \\
\hline Ingdp & 380 & 9.949 & 1.027 & 6.717 & 11.250 \\
\hline Inepu & 365 & 7.150 & 0.440 & 5.781 & 8.617 \\
\hline Inco2pc & 300 & 1.895 & 0.747 & -0.036 & 3.005 \\
\hline Into & 380 & 4.217 & 0.747 & 2.986 & 6.093 \\
\hline Indcps & 365 & 4.479 & 0.649 & 2.555 & 5.452 \\
\hline Inrnd & 339 & 0.250 & 0.727 & -2.040 & 1.516 \\
\hline Inpopg & 334 & -0.352 & 0.902 & -4.668 & 1.672 \\
\hline Inene & 312 & 7.967 & 0.742 & 6.031 & 9.043 \\
\hline
\end{tabular}

This table reports descriptive statistics of our variables. These statistics are observations (Obs), mean, standard deviation (SD), minimum (Min), and maximum (Max) values.

is acknowledged to produce consistent results since it addresses the problems of endogeneity and omitted variable issues (Appiah-Otoo \& Song, 2021). To address endogeneity issues, we use the first and second lags of EPU as instruments. For our robustness analysis, we use the ordinary least squares (OLS), estimator.

\section{RESULTS AND DISCUSSION}

Table 2 reports descriptive statistics. RE growth recorded an average of $2.51 \%$ with a maximum growth of $4.49 \%$. Hydroelectric power had the highest average, indicating the dominance of hydroelectricity in the RE energy mix. The standard deviations of all the variables were below the mean value, indicating that the variables are not volatile, except population growth, technological innovation, and other renewable energy sources.

Table 3 reports results. Models 1-3 present the OLS estimates while Models 4-6 present the IV-GMM estimates. The results show that EPU has an insignificant but negative effect on total RE growth, hydroelectricity, and other RE sources. We further find that: economic growth drives other RE sources growth and it impedes hydroelectricity growth; trade openness impedes total RE, hydroelectricity, and other RE sources ; financial development impedes other RE sources growth while it promotes hydroelectricity growth; energy consumption impedes other RE sources growth while it promotes RE and hydroelectricity growth; population growth promotes other RE sources growth; technological innovation impedes hydroelectricity and total RE growth while it promotes other RE sources growth; and carbon emissions impede hydroelectricity and total RE growth. The significant negative effect of carbon emissions on total $\mathrm{RE}$ is consistent with the results obtained by Olanrewaju et al. (2019), who study five African countries and find that carbon emissions reduce RE growth.

It can be seen that the coefficients of the IV-GMM estimates are marginally bigger compared to the OLS estimates, demonstrating that the IV-GMM approach addresses omitted variable bias. The probability values of the Hansen test show that the instruments used are valid in the IVGMM models. Finally, the variance inflation factors of the OLS estimates are below 10, demonstrating that our study does not suffer from the problem of multicollinearity.

Table 4 presents the causality analysis based on the Dumitrescu \& Hurlin (2012) causality test. The results show that there is no evidence of causality between EPU, RE growth, hydroelectricity, and other RE sources. This implies that EPU does not explain changes in RE growth, whilst RE does not explain EPU.

\section{CONCLUSION AND POLICY RECOMMENDATIONS}

With global warming and climate change being the major environmental issues of the $21^{\text {st }}$ century, policymakers throughout the world have embraced renewable energy (RE) into their policies. This has seen RE growth; however, its deployment remains low compared to other sources of energy.

This study estimates the effect of economic policy uncertainty (EPU) on RE growth for a panel of 20 countries covering the 2000 to 2018 period. By utilizing the IV-GMM model, we find that EPU has an insignificant negative effect on RE growth. The results from the causality analysis also indicate no evidence of causality between EPU and RE growth. These results are robust to the disaggregation of RE into hydroelectricity and other RE sources.

Although the findings show that EPU does not explain RE growth, the statistically insignificant results may just be a result of a smaller sample size (timewise, as we use only 18 years of data). Hence, focusing on the sign of the relation, the negative sign implies that policymakers should adopt long-term RE plans to ensure that a rise in EPU does not interrupt RE production.

\section{Acknowledgement}

Helpful comments and suggestions from the Editor and 
Table 3: Economic policy uncertainty and renewable energy growth

\begin{tabular}{|c|c|c|c|c|c|c|}
\hline & Model 1 & Model 2 & Model 3 & Model 4 & Model 5 & Model 6 \\
\hline & & OLS & & & IV-GMM & \\
\hline Variables & Hydro & Others & Total & Hydro & Others & Total \\
\hline \multirow[t]{2}{*}{$\operatorname{lngdp}$} & $-0.758^{* * *}$ & $1.548^{* * *}$ & -0.092 & $-0.775^{* * *}$ & $1.608^{* * *}$ & -0.085 \\
\hline & $(0.168)$ & (0.171) & $(0.184)$ & $(0.176)$ & $(0.180)$ & (0.197) \\
\hline \multirow[t]{2}{*}{ Inepu } & -0.265 & -0.136 & -0.258 & -0.460 & -0.312 & -0.441 \\
\hline & $(0.222)$ & $(0.203)$ & $(0.176)$ & (0.371) & (0.308) & (0.303) \\
\hline \multirow[t]{2}{*}{$\operatorname{Inco} 2 p c$} & $-3.208^{* * *}$ & -0.375 & $-2.278^{* * *}$ & $-3.108^{* * *}$ & -0.129 & $-2.202^{* * *}$ \\
\hline & $(0.286)$ & $(0.286)$ & (0.305) & $(0.287)$ & $(0.302)$ & $(0.310)$ \\
\hline \multirow[t]{2}{*}{ Into } & $-1.237^{* * *}$ & $-0.838^{* * *}$ & $-1.330^{* * *}$ & $-1.284^{* * *}$ & $-0.939^{* * *}$ & $-1.400^{* * *}$ \\
\hline & (0.187) & (0.174) & (0.174) & (0.198) & (0.177) & (0.179) \\
\hline \multirow[t]{2}{*}{ Indcps } & $0.353^{* *}$ & $-0.403^{* *}$ & -0.168 & $0.418^{* * *}$ & $-0.519^{* *}$ & -0.165 \\
\hline & (0.149) & $(0.204)$ & (0.187) & (0.154) & $(0.215)$ & $(0.207)$ \\
\hline \multirow[t]{2}{*}{ Inrnd } & $-1.245^{* * *}$ & $0.838^{* * *}$ & $-0.553^{* * *}$ & $-1.177^{* * *}$ & $1.105^{* * *}$ & $-0.443^{*}$ \\
\hline & (0.190) & $(0.210)$ & $(0.208)$ & (0.194) & $(0.230)$ & $(0.228)$ \\
\hline \multirow[t]{2}{*}{ Inpopg } & 0.067 & $0.491^{* * *}$ & 0.028 & 0.118 & $0.498^{* * *}$ & 0.097 \\
\hline & (0.088) & $(0.095)$ & $(0.085)$ & $(0.084)$ & (0.098) & (0.092) \\
\hline \multirow[t]{2}{*}{ Inene } & $4.045^{* * *}$ & $-1.441^{* * *}$ & $2.526^{* * *}$ & $3.868^{* * *}$ & $-1.877^{* * *}$ & $2.386^{* * *}$ \\
\hline & (0.519) & (0.472) & (0.572) & (0.523) & $(0.497)$ & $(0.580)$ \\
\hline \multirow[t]{2}{*}{ Constant } & $-10.913^{* * *}$ & 3.635 & -4.223 & $-8.201^{* *}$ & $8.254^{* *}$ & -1.703 \\
\hline & $(3.045)$ & (2.891) & (2.743) & (3.715) & (3.581) & (3.396) \\
\hline Observations & 210 & 229 & 230 & 181 & 200 & 200 \\
\hline$R^{2}$ & 0.555 & 0.375 & 0.523 & 0.576 & 0.404 & 0.538 \\
\hline RMSE & 1.176 & 1.323 & 1.225 & 1.111 & 1.283 & 1.221 \\
\hline F-statistic & 43.879 & 21.611 & 35.404 & 40.358 & 22.338 & 33.005 \\
\hline$J$ & & & & 0.167 & 0.203 & 0.248 \\
\hline$J P$ & & & & 0.682 & 0.653 & 0.619 \\
\hline Mean VIF & 6.89 & 6.29 & 6.29 & & & \\
\hline
\end{tabular}

This table reports our OLS and IV-GMM results. The robust standard errors are presented in parentheses. The Hansen $J$-statistic is represented by $J$. The Hansen $J$-statistic $p$-value is represented by $J P$. The weak instrument identification is represented by the $F$-statistic. Mean VIF denotes the mean variance inflation factor. The standard deviation of the residuals is represented by Root Mean Square Error (RMSE). Finally, ${ }^{*} p<0.1,{ }^{* * *} p<0.05$, and ${ }^{* * * *} p<0.01$.

Table 4: Causality analysis

\begin{tabular}{lc}
\hline Null hypothesis & F-statistic \\
\hline Inepu does not Granger-cause Inre & 1.223 \\
Inre does not Granger-cause Inepu & 0.679 \\
Inepu does not Granger-cause Inhydro & 1.063 \\
Inhydro does not Granger-cause Inepu & 0.104 \\
Inepu does not Granger-cause Inothers & 0.508 \\
Inothers does not Granger-cause Inepu & 0.347 \\
\hline
\end{tabular}

This table reports the causality analysis based on the Dumitrescu \& Hurlin (2012) causality test.

an anonymous reviewer of this journal are acknowledged. 


\section{REFERENCES}

Al-Thaqeb, S. A., \& Algharabali, B. G. (2019). Economic policy uncertainty: A literature review. Journal of Economic Asymmetries, 20, e00133. https://d oi.org/10.1016/j.jeca.2019.e00133

Appiah-Otoo, I. (2020). Does COVID-19 Affect Domestic Credit? Aggregate and Bank Level Evidence From China. Asian Economics Letters, 1(3), 18074. http s://doi.org/10.46557/001c.18074

Appiah-Otoo, I., \& Song, N. (2021). The impact of ICT on economic growth-Comparing rich and poor countries. Telecommunications Policy, 45(2), 102082. $\underline{\mathrm{h}}$ ttps://doi.org/10.1016/j.telpol.2020.102082

Baker, S. R., Bloom, N., \& Davis, S. J. (2016). Measuring economic policy uncertainty. The Quarterly Journal of Economics, 131(4), 1-52. https://d oi.org/10.1093/qje/qjw024.Advance

Balcilar, M., Roubaud, D., \& Shahbaz, M. (2019). The Impact of Energy Market Uncertainty Shocks on Energy Transition in Europe. The Energy Journal, 40(01), 55-79. https://doi.org/10.5547/01956574.40.si $1 . \mathrm{mbal}$

Barradale, M. J. (2010). Impact of public policy uncertainty on renewable energy investment: Wind power and the production tax credit. Energy Policy, 38(12), 7698-7709. https://doi.org/10.1016/i.enpol.20 $\underline{10.08 .021}$

Bourcet, C. (2020). Empirical determinants of renewable energy deployment: A systematic literature review. Energy Economics, 85, 104563. http s://doi.org/10.1016/i.eneco.2019.104563

Cao, H., Guo, L., \& Zhang, L. (2019). Does oil price uncertainty affect renewable energy firms' investment? Evidence from listed firms in China. Finance Research Letters, 33, 1-7. https://doi.org/10.1 016/j.frl.2019.06.003 da Silva, P. P., Cerqueira, P. A., \& Ogbe, W. (2018). Determinants of renewable energy growth in SubSaharan Africa: Evidence from panel ARDL. Energy, 156, 45-54. https://doi.org/10.1016/j.energy.2018.0 $\underline{5.068}$

Dumitrescu, E.-I., \& Hurlin, C. (2012). Testing for Granger non-causality in heterogeneous panels. Economic Modelling, 29(4), 1450-1460. https://doi.or $\mathrm{g} / 10.1016 /$ j.econmod.2012.02.014

Fabrizio, K. R. (2013). The effect of regulatory uncertainty on investment: Evidence from renewable energy generation. Journal of Law, Economics, and Organization, 29(4), 765-798. https://doi.org/10.1093/ jleo/ews007

Hsieh, H.-C., Boarelli, S., \& Vu, T. H. C. (2019). The effects of economic policy uncertainty on outward foreign direct investment. International Review of Economics \& Finance, 64, 377-392. https://doi.org/1 0.1016/j.iref.2019.08.004

Iyke, B. N. (2020). Economic Policy Uncertainty in Times of COVID-19 Pandemic. Asian Economics Letters, 1(2). https://doi.org/10.46557/001c.17665

Li, X. (2019). Economic policy uncertainty and corporate cash policy: International evidence. Journal of Accounting and Public Policy, 38(6), 106694. http s://doi.org/10.1016/i.jaccpubpol.2019.106694

Nguyen, C. P., Le, T.-H., \& Su, T. D. (2020). Economic policy uncertainty and credit growth: Evidence from a global sample. Research in International Business and Finance, 51, 101118. https://doi.org/10.1016/j.ribaf.20 19.101118

Olanrewaju, B. T., Olubusoye, O. E., Adenikinju, A., \& Akintande, O. J. (2019). A panel data analysis of renewable energy consumption in Africa. Renewable Energy, 140, 668-679. https://doi.org/10.1016/j.renen e.2019.02.061 